turns out to be a disaster and Lee's parents leave early after a heated argument between her and her father. This chapter accentuates Lee's class-related anxiety and illustrates her liminal position between a home from which she feels alienated and a school she cannot claim as her own. The sixth chapter, "Townie," begins with Sin-Jun's attempted suicide and Lee's racist shock and surprise at her ex-roommate's depression. At the hospital, Lee meets Dave, who is part of the Ault kitchen staff and asks her to dinner. Though she initially accepts his invitation, she ultimately cancels because she does not want to be seen with a "townie" (242) who lacks the money and manners of an Ault student. The seventh chapter, "Spring-cleaning," returns to Lee's academic issues. She has to pass an important math exam or else be "spring-cleaned" (255), i.e. be asked to leave Ault. While Martha (and Cross) are elected senior prefect-the school's most prestigious position-Lee almost fails her exam and passes only because of Martha's help. The fact that her roommate and her love interest both succeed at Ault serves to accentuate Lee's failure further. In the last chapter, "Kissing and Kissing," Lee begins an affair with Cross, carried out secretly in the day student room. While she is in love with him, he does not seem interested in her as a girlfriend. They meet regularly and sleep together, but toward the end of the school year, the relationship ends, leaving Lee sad and confused. When she is asked by the school's headmaster to be interviewed by a New York Times reporter who is working on a feature on Ault, she accepts. She tells the reporter more than she wants to about her experience as a lower-middle-class "nobody from Indiana" (363) and is shocked when the article comes out and is met with criticism and resentment from her peers and her parents. The novel ends with a brief glimpse into the future, recounting the personal and professional paths chosen by the main characters.

\title{
3. Prep in the Discourse: Publicity, 'Preppiness', and the Neoliberal Imagination
}

Prep was published on January 18, 2005, with an original run of just 13,000 copies. ${ }^{4}$ Despite initial doubts, the novel sold well, and Random House quickly responded to its increasing popularity by adding another 24,000 copies. Both the hardcover and the paperback edition eventually became bestsellers. Prep 
was translated into several languages and chosen as one of the best books of 2005 by Slate, The Washington Post, The Chicago Tribune, and a number of smaller newspapers and magazines ${ }^{5}$; Paramount optioned the movie rights (Boss). Perhaps most importantly, The New York Times included the novel as one of its ten best books of 2005, thus putting Sittenfeld into the ranks of Haruki Murakami, Zadie Smith, Joan Didion, and Ian McEwan. Prep was furthermore long-listed for the prestigious Orange Prize. Some of the reviews, however, and, notably, Sittenfeld's own account of her initial success also point to the less successful prelude to the novel's publications: The manuscript was rejected by fourteen out of fifteen publishers (Sittenfeld 2005). Sittenfeld's literary agent, Shana Kelly, explains that the publishers "loved it but weren't sure they could sell a lot of copies, because they couldn't figure out how to market it" (quoted in Boss). On the one hand, this is noteworthy because it points to the novel's genre hybridity, which plays a role in determining its position in the discourse. On the other hand, and perhaps more importantly, the mythologization of the novel's genesis transforms Prep into the protagonist of precisely the kind of obstacles-overcome success story that, I argue, the diegesis resists and potentially subverts. In the following, I introduce and discuss in detail the novel's discursive position, beginning with the marketing campaign that established it as a fun take on an American subculture, before moving on to professional and lay reviews, which emphasized Prep's treatment of class and status, and, finally, academic perspectives, which criticized the novel as an expression of neoliberal ideology.

\section{'Preppification'}

The story of the novel's triumphant marketing began with the change of its original title, Cipher, into the decidedly more evocative Prep, and the matching publicity campaign developed by a team of young and "extremely on-theball" (Sittenfeld 2005) publicists at Random House. Press materials for Prep featured Sittenfeld's Groton School class photograph and yearbook page, as well as a picture of her high school crush (Lee). The campaign furthermore included gift baskets for editors at women's magazines, which, as Sittenfeld explains, came in the form of "translucent pink oversize Chinese-food cartons containing, along with Prep, items reminiscent of what teenage girls take 
with them to school: flip-flops, notebooks, Lip Smacker lip gloss" (Sittenfeld 2005). In allusion to the novel's cover, which showed a "supremely cute pinkand-green grosgrain-ribbon belt" (ibid.), Prep-inspired belts were given out at readings. Random House credits the "catchy title and book cover and creative marketing and publicity" (Boss) with the novel's unexpected success, and Sittenfeld herself admits that she cannot disagree with those who "railed against Prep as a "corporate hype job" (2005).

The marketing campaign capitalized on the novel's prep school setting and thus opened up a discursive space that is very different from that discussed in the reviews, which I address in more detail below. As Sittenfeld herself asks: "[G]iven that Prep is sometimes a dark book, with commentary on class and gender, what was up with the festive jacket?" (ibid.). Preppies feature in the American cultural landscape at least since working-class Radcliffe student Jenny Cavalleri famously dubbed her future husband Oliver Barrett a "preppy" in the hugely popular film Love Story (1970; dir: Arthur Hiller), pointing out that he looked "stupid and rich." Since then, depictions of the preppy way of life have always been tongue-in-cheek, simultaneously mocking and celebrating this particular American cultural formation. Notable publications in this context include Nelson W. Aldrich's article "Preppies: The Last Upper Class?" (1979) and the tremendously successful Official Preppy Handbook (1980). Aldrich offers a description of what he calls "a small but usually recognizable species of Americans" (56), arguing that "Preppie' is a catch-all epithet to take the place of words too worn or elaborate for everyday use, words such as privileged, ruling class, aristocrat, society woman, gentleman, and the rich" (ibid., emphasis in the original). His article explores the cultural characteristics and practices associated with preppiness, ranging from money, status, and prep school affiliation to fashion, mannerisms, and values. Shortly after Aldrich's musings were published in The Atlantic, the perhaps definitive 'preppy' publication entered the discourse: The Official Preppy Handbook, edited by Lisa Birnbach. A tongue-in-cheek how-to guide to preppy culture, the Handbook has figured in recent years as one of the founding texts of a whole collection of blogs dedicated to the preppy way of life $^{6}$ and has thus maintained its cultural relevance despite being out of print. 
Even though more than two decades lie between these two publications and Sittenfeld's novel, it is important to situate the latter in this discursive context, since much of its appeal derives from this connection. In an interview, Sittenfeld herself addressed the Preppy Handbook's influence on her understanding of the subject matter (cf. Wood), and it is thus not surprising that her novel features a number of more or less oblique references to the Handbook, thus further establishing the connection: Lee points out, for instance, that unlike her boarding school peers she "did not have, among other things, a middle name" (69), and wonders whether she should give herself one when she goes off to college (308). The Preppy Handbook emphasizes the cultural importance of middle names by mentioning in its very first chapter that "Mummy and Daddy have carefully selected first and middle names (at least one of each)" (Birnbach 15). Lee furthermore drily mentions that her peers' mothers "had names that made it hard to imagine they'd ever held real jobs: Fifi and Tinkle and Yum" (167), thus invoking the Preppy Handbook's list of the most popular preppy nicknames, which include Kiki, Topsy, Tiffy, Bitsy, and Corkie (Birnbach 18). The color palette of the novel's cover furthermore alludes to a section in the Preppy Handbook, titled "The Virtues of Pink and Green," which points out that "[t]he wearing of the pink and the green is the surest and quickest way to group identification within the Prep set" because "no one else in his right mind would sport such a chromatically improbable juxtaposition" (Birnbach 156). The reader is then asked to color the illustration accordingly.

What most publications dealing with preppiness-and in particular Aldrich's and the Preppy Handbook's take-have in common is a depoliticization of their subject matter: Aldrich, for instance, points out that "[i]deological struggle is too shaming to talk about these days. Life-style rivalry is the new engine of history" (56). Both emphasize the quaintness and eccentricities of 'prepdom'-the obsession with nautical imagery, for instance, or the "unwavering taste for luminescent pastels and hard primary colors, a taste evidently designed to evoke the infantile gaiety of the nursery" (Aldrich 59). Both furthermore stress the alleged openness of preppy culture. While Aldrich claims that there are two types of Preppies, "the self-made and the hereditary" (57), the Preppy Handbook as a whole comes in the guise of a Howto guide and, in its opening remarks, makes the following claim:

It is the inalienable right of every man, woman and child to wear khaki. Looking, acting, and ultimately being Prep is not restricted to an elite minority 
lucky enough to attend prestigious private schools, just because an ancestor or two happened to arrive here on the Mayflower. You don't even have to be registered Republican. In a true democracy everyone can be upper class and live in Connecticut. It's only fair. The Official Preppy Handbook will help you get there. (Birnbach 11)

Given this emphasis on becoming part of the preppy culture, it is not surprising that the insistence on the novel's preppiness also connects it to a specific segment of contemporary American consumer culture. This begins with the grosgrain ribbon belts given out at readings-these belts are typically produced by traditional American brands such as Brooks Brothers and Vineyard Vines-and also manifests itself in a Newsweek style segment, in which an L.L.Bean Tote bag is described as "perfect for your new copy of Prep." A brand long associated with affluent New Englanders, L.L.Bean is mentioned several times in The Official Preppy Handbook, and experienced a "record year" upon its publication and the concomitant preppy boom-its business "nearly doubled in two years" (Gorman 143). Similarly, Arthur Cinader founded the clothing line J.Crew in 1983 "in the hopes of capitalizing on the success of The Official Preppy Handbook" (Bourne). It is important to note that Prep directly contradicts the popular notion of preppiness as a lifestyle choice. The novel is primarily concerned, after all, with the protagonist's failure to become part of her preppy surroundings, showing that contrary to the Handbook's assertion, it does take more than a pair of khaki slacks to do so.

Prep has to be situated in this context because doing so demonstrates how the novel both benefits from existing cultural structures and practices around the signifier 'prep' and, in turn, helps to generate some of its own. It also illustrates the interweaving of different positions in the discourse: Fiction, fashion, consumer practices, and cultural knowledge are all part of the same citational system and gravitate around the same signifiers, feeding on similar cultural meanings. The overlap of the narrative of merit, class, and consumer culture is summed up perfectly by the description of Prep in People Magazine: "Straight As get Lee into the Ault School on scholarship, but fitting into the Abercrombie crowd is tougher" ("Picks and Pans").

Interestingly, all of this happens shortly after a presidential campaign in which two graduates of exclusive preparatory schools competed for the presidency: John Kerry graduated from St. Paul's School in New Hampshire in 1962, and George W. Bush's alma mater is Phillips Academy Andover, where his father had gone before him. Kerry and Bush are also both affiliated with another 
elite institution: Yale University and its secret society Skull and Bones. Prep comments on the importance of famous graduates when Lee's parents recognize the names of renowned politicians and actors:

I had told them before about these alumni, [...] who'd gone on to acclaim; to people outside the school, it was the existence of famous graduates-and not, say, current students' median SAT scores- that seemed to most validate Ault. At home, if my parents' friends knew one thing about the place I went to school, it wasn't where it was or even what it was called; it was the names of the celebrities who'd graduated before me. (181)

Though referenced in this quote, the actual socio-political power held by elite educational institutions has not entered the discourse of 'preppiness' in any meaningful way. When the LA Times claims that "[p]rep schools have become fiction's 'new black"' (Shin), or Carol McD. Wallace-one of the original cowriters of The Official Preppy Handbook-confidently states that "We're All Preppies Now," they are referring to cultural and aesthetic aspects only. There was and still is very little awareness in these kinds of discursive positions as to the actual role exclusive preparatory schools play in the United States. Still, all of this suggests that 'preppiness'-in all its various meanings-was very much in the air in early 2005.

\section{Reviews of Prep}

On popular rating and discussion platforms such as Goodreads and Amazon, Prep has received mixed reviews. On Amazon, the novel received 592 reviews with an average rating of 3.3 out of 5 stars, and on Goodreads, it received 3,368 reviews and 46,325 ratings, with an overall score of 3.33 out of 5 stars. Goodreads also tells us that 79 percent of its readers "liked" the novel, though it does not specify exactly what that means. A comparison with some of the other novels listed as "Best Books of 2005" in The New York Times demonstrates that Prep has received a relatively high number of reviews in relation to the somewhat moderate number of ratings. Assuming that those who write a review of a novel also rate it, it follows that one in thirteen raters has written a review for Prep, whereas only one in fourteen reviewed McEwan's Saturday, one in fifteen reviewed Murakami's Kafka on the Shore, and one in seventeen reviewed Smith's White Teeth. Given these discrepancies, it is not far-fetched to assume that while fewer people 'liked' Prep than the other novels, it generated stronger opinions, and prompted readers to share them online. A compari- 
son with other recent campus novels further illustrates Prep's popularity and reach:

Professional reviews ${ }^{7}$ were overwhelmingly positive; as Hank Stuever pointed out in the Washington Post, Prep was received with "near universal praise" and became an "immediate success." Tom Perrotta called it "[o]ne of the most impressive debut novels in recent history" (quoted in "Prep: A Novel"). In addition to the Post, the novel was reviewed in The New York Times, The New York Observer, Newsweek, The New Yorker, Slate, People Magazine, Guardian, The Chicago Tribune, and a host of less well-known news outlets. Reviewers almost universally lauded Sittenfeld's style and her attention to detail-the "exacting intimacies" of a "richly textured narrative" (The New Yorker), her "craft and detail" (Earth Goat), the novel's "almost clinically accurate and absorbing glimpse into the daily life of an exclusive, privileged place" (Stuever). The Washington Post Book World praised "Sittenfeld's perfect pacing and almost reportorial knack for describing what it's like-psychologically, logistically-to be fifteen" ("Curtis Sittenfeld: Prep"). Dave Eggers called her prose "sharp and economical" and commended her "sly and potent wit, which cuts unexpectedly" (quoted in "Prep: A Novel"). Criticism was leveled against the somewhat slow plot: Elissa Schappell in The New York Times complained that " $[r]$ ead as fiction, Sittenfeld's novel sets up dramatic expectations that aren't met," while Laken pointed out that "many of the novel's events are predictable." People Magazine complained, in an otherwise positive review, that "there's not much of a story here."

Taken collectively, the reviews gravitate to three nodal points: class, agency, and authenticity. The reviewers seem to agree that class is at the heart of the novel. Felicia R. Lee states that "Prep is very much a novel about class"; Schappell wants to see the novel on every summer reading list because of "the incisive and evenhanded way in which Sittenfeld explores issues of class," Laken praises Sittenfeld for "illuminat[ing] the way class lines divide students not externally but internally," and Wood concludes that "Prep is largely about one girl's discovery of class and her subsequent learning curve." It is striking to see, however, that hardly any of the reviews actually engage with the issue of class (in the novel or elsewhere) in any depth. Schappell is one of the few who ventures a little deeper, only to conclude that Lee's story demonstrates "a lesson some never [learn]: that the rich cannot only be complex and interesting, they can teach a judgmental middle-class girl

7 I have read and analyzed roughly twenty-five reviews of the novel. 
something about tolerance and grace." Statements such as this already point to the novel's complicated and problematic treatment of class, discussed in more detail below.

A second nodal point generated in the reviews is the question of agency and the attribution of blame. Reviewers agree that Lee's story is largely a story of failure-in many ways, the novel is reminiscent of the "meritocracy lamenters" misery memoirs (cf. Koganzon 108) discussed in the second chapter of this study. Even though the contrast between her lower-middle-class background and the elite environment at Ault is related to her inability to cope, most reviewers hold Lee herself responsible for the difficulties she experiences at the school. Stuever calls Lee "the unlovably self-conscious narrator" and points out that due to "her complete inarticulateness and shyness, she makes a high school career of marginalization," thus perhaps insinuating that she actively and consciously attempts to capitalize on her marginality. Laken refers to Lee as a "highly sensitive girl adrift-by her own volition" and concludes that "what isolates Lee is not anything as unchangeable as her face or her pocketbook, but the more complicated matters of her personality and her own resistance." Schappell argues that "Lee is not saint, and no victim, but rather a willing cog in the machine of exclusion," and Hulbert sees Lee's trajectory as "neither peripatetic nor tragic" since it is Lee herself who makes sure that "no one could catch her being intellectually committed, socially invested, or emotionally engaged." By individualizing Lee's experiences at Ault, the reviewers thus depoliticize the novel's position on class-Lee's failures are attributed to her personal inadequacy, and not to systemic factors.

The third nodal point structuring the majority of reviews is the notion of authenticity and, related, that of verisimilitude. If, following People Magazine, Prep offers a "voyeuristic trip inside an enclave of privilege," reviewers want to know whether the novel's observations are 'authentic'. It is important to note, however, that this is not only an issue of whether or not the portrayal of the elite educational experience is deemed realistic and convincing or not, but very much rests on Sittenfeld's author position. As a graduate of Groton, she is depicted as having a legitimate claim to tell the story. The importance of this notion of membership again reflects the incestuousness of the discourse of elite education discussed already in the context of the critical-analytical studies. The reviews are thus full of gestures of authenticity and legitimacy that seem necessary to establish credibility within this discourse: Schappell states that "Sittenfeld's dialogue is so convincing that one wonders if she didn't wear a wire under her hockey kilt" and concludes that 
Prep "feels like a memoir." Laken similarly points out that the "narrator's voice is crafted so naturally that the novel has the feeling of a memoir or a girl's diary." Furthermore, thanks to Random House's successful publicity campaign, Sittenfeld's ties to Groton are common knowledge. Few reviews thus get by without asking "How much of the first-person book is Curtis and how much is Lee?" (Lee). Stuever concludes that "it's hard to really know how much of Prep is autobiography." In her many interviews, Sittenfeld concedes that the novel's Ault School is based on Groton, but otherwise stresses its fictionality, pointing out that it is a "very plotted book" and that only "few of the characters are composites or based on real people" (quoted in Lee). Felicia R. Lee dedicates an entire article in The New York Times to the question of autobiography, titled somewhat awkwardly: "Although She Wrote What She Knew, She Says She Isn't What She Wrote." Colleen Long, writing for the San Diego Union-Tribune, puts it more poignantly: "Author Not Neurotic Dork of Prep." In many ways, this emphasis on the author's claim to her narrative is distinctive to the discourse of elite education, which does not seem to allow outsiders to participate to any meaningful extent.

Almost all of the reviews create intertextual connections between Prep and other novels and films, thus positioning the text within the landscape of fictional explorations of the elite educational space. Perhaps the most common comparison is that with J.D. Salinger's The Catcher in the Rye: The US News \& World Report reports that "[f]or everyone who wished that Holden Caulfield was a girl, your time has come" ("Curtis Sittenfeld: Prep"); the Washington Post's title says "Move over, Holden: Curtis Sittenfeld Writes About Boarding School Life as if She's Been There" (Stuever). The basis for this comparison seems to be no more substantive than the boarding school setting-even though large parts of Catcher in the Rye do not, in fact, take place at Pencey Prep-and Sittenfeld herself, while "incredibly flattered," does not really see many similarities between the two novels (2005). Most of the other texts mentioned in reviews share the elite setting: Dead Poets Society, John Knowles's A Separate Peace, Tom Wolfe's I am Charlotte Simmons, Donna Tartt's The Secret History, the Harry Potter series, and Clueless. Because Sittenfeld's protagonist is female and unhappy, and because the author was the winner of the Seventeen Magazine fiction contest in 1992, there is a fair share of Sylvia Plath comparisons as well. Surprisingly few intertextual connections stress the issue of class, such as The $O C$, The Great Gatsby, and the novels of Edith Wharton. One reviewer alludes to "the old kind of class novel-about striving and trying to move up by learning the upper-class code" and mentions Dreiser and Crane as possible points of 
comparison (McGrath). All in all, it is interesting to note that even though the reviews stress the novel's examination of class and alienation, the boarding school setting seems to dominate completely in terms of intertextual connections. Interestingly, none of the reviews mentions any of the other, more recent campus novels set at elite boarding schools or colleges, for instance Tobias Wolff's Old School (2003) or Tom Perrotta's Joe College (2000), both of which feature protagonists who, like Lee, do not fit in at their elite institutions, but who are more successful in trying to overcome their outsider status. Another curious absence is the Gossip Girl series, whose first installment was published in 2002, and which is set at a private school in Manhattan and features two middle-class characters adrift in the world of privilege.

There is a noticeable disconnection between the signifiers mobilized by the marketing campaign and the reviews of the novel. The publicity generated by Random House's Team Prep revolved around the signifier 'preppiness', which suggested a quirky, fun take on an American "subculture." The items involved in the campaign - the belts, the gift baskets, the yearbook pages-point toward the genre of Chick Lit. The reviews, however, almost unanimously read Prep as a serious novel about class (and, to a lesser extent, race and gender) at an elite boarding school, and while most of them acknowledge the specificities of the setting, many also mention the novel's universality: According to Newsday, "Sittenfeld captures the universal conundrum of teen life," while The Detroit News praises her for being "superb at [...] floating ideas about human nature, education and the society that invented prep schools" "Curtis Sittenfeld: Prep"). Many of the reviews talk about Sittenfeld capturing 'high school experience' or 'adolescence' perfectly, thus abstracting the novel from its immediate setting at an exclusive private boarding school. Prep's treatment of class is therefore likewise seen as a more general statement about socio-economic issues in the United States, not just on the elite campus. As this brief overview has demonstrated, Prep has not only reached a surprisingly large readership, but was also overwhelmingly taken seriously as a commentary on class and elite education in the United States. My discussion of the most prominent reviews has also illustrated, however, that only very few use Prep as a point of departure to actually think about (in)equality, class, education, and notions of Americanness. 


\section{Academic Criticism: Prep and the Neoliberal Imagination}

Overall, Prep has generated relatively little academic attention. ${ }^{8} \mathrm{~A}$ few months after its publication, however, Walter Benn Michaels published an article titled "The Neoliberal Imagination," in which he reads Prep alongside Tom Wolfe's I am Charlotte Simmons, a reading that later also finds its way into his muchdiscussed The Trouble with Diversity (2006). In the following, I want to take up and expand on Michaels's reading, which I find in equal parts compelling and reductive. Building on the notion of a 'neoliberal imagination' I want to interrogate the novel's complex relationship with the larger discursive context in which it was produced-a context in which neoliberalism is the dominant mode of meaning-making.

\section{Neoliberalism}

Before thinking in more detail about the peculiarities of the neoliberal imagination, a brief excursus on neoliberalism itself is necessary. Of course, whole books have been written in the attempt to offer a taxonomy of what Loïc Wacquant calls a "slippery, hazy and contentious category" (68). Indeed, according to Jane Elliott and Gillian Harkins, neoliberalism has become "such a crossdisciplinary buzzword in recent years that some scholars suggest 'neoliberalism fatigue' may be settling in" (2). My account of the concept, then, will of necessity be brief and schematic, but nonetheless important to understanding Prep's position within the neoliberal imagination.

According to Clive Barnett, neoliberalism evolved out of a "family of ideas" developed in the context of a revitalization and rethinking of economic liberalism in the mid-twentieth century (269). The success story of neoliberalism, Barnett continues, is told and re-told "through a standardized narrative that touches on a series of focal points:"

[A] period of economic crisis which shook the foundations of the postSecond World War, Keynesian settlement as the conjuncture in which previously marginal neoliberal economic theories were translated into real-world policy scenarios; the role of economists from the University of Chicago in Pinochet's Chile in the 1970s, Reagonomics in the USA in the 1980s, and so-called Thatcherism in the UK in the 1980s; the role of key 
international agencies, such as the International Monetary Fund (IMF) and World Bank as being responsible for diffusing neoliberalism globally through the so-called Washington Consensus in development and foreign aid policy; and the taken-for-granted claim that neoliberalism has, over time, been transformed from an ideology into common sense. (270)

This brief narrative already suggests a number of different dimensions on which the term 'neoliberalism' operates. On the one hand, as an economic theory and as the practical implementation of that theory in specific localized contexts, but on the other hand, in a broader sense, as an "ideational project" (Barnett 270) that seeks to create the subjectivities it needs in order to function. Even more broadly, neoliberalism is understood as what David Harvey calls a "hegemonic [...] mode of discourse" (23): twenty-first century common sense. Since it has been pointed out time and again that neoliberalism in its purest form actually does not exist anywhere and the "theoretical utopianism of the neoliberal argument has worked more as a system of justification and legitimization" (Harvey 29)-retrospectively, rather than proactively, as it were-Barnett also introduces the term 'neoliberalization' to describe the various geographically and temporally uneven processes associated with the diffusion, articulation, and normalization of neoliberal thought (270).

If we assume that neoliberalism is involved in a constant struggle to create the subjectivities that enable it to function, and if we assume further that these subjectivities are not only created through the channels mentioned above-the economy, politics, the law-then it becomes imperative to trace neoliberal ideas and principles in the everyday images and texts we encounter, the practices in which we engage, the beliefs and convictions we have come to claim as our own. Thus, when a young student activist from the Netherlands yells "Yeah, fuck the neoliberal narrative" (quoted in D'Astous and Gerlings), she is referring to much more than her country's economic policies or the mindset of those institutions that regulate global finance and commerce, i.e. the International Monetary Fund (IMF) and the World Trade Organization (WTO). She is referring to something much larger and yet more elusive, something which Wacquant, borrowing from Pierre Dardot and Christian Laval, calls a “'generalized normativity', a 'global rationality' that 'tends to structure and organize, not only the actions of the governing, but also the conduct of the governed themselves' and even their self-conception according to principles of competition, efficiency, and utility" (69-70). 
A helpful concept to make sense of the range and reach of neoliberalism is Michel Foucault's notion of 'governmentality', developed in a set of lectures at the Collège de France in 1978 and 1979. Etymologically, the term 'governmentality' derives from the French gouvernemental ("concerning government") and had already been used by Roland Barthes, albeit with a different meaning (Lemke 44). In his thoughts on power, Foucault argues for an opening of the notion of government:

This word must be allowed the very broad meaning it had in the sixteenth century. 'Covernment' did not refer only to political structures or to the management of states; rather, it designated the way in which the conduct of individuals or of groups might be directed-the government of children, of souls, of communities, of families, of the sick. It covered not only the legitimately constituted forms of political or economic subjection but also modes of action, more or less considered and calculated, that were destined to act upon the possibilities of action of other people. To govern, in this sense, is to structure the possible field of action of others. (2000: 341)

The notion of neoliberal governmentality as a force that influences regimes and individuals alike helps to grasp the reach of the various neoliberalisms - transcending economic theory and political programs and entering cultural practices, everyday behaviors and consumption patterns, and, ultimately, the aesthetics and politics of twenty-first-century self-making. Thinking about neoliberalism through the lens of governmentality thus allows us to trace its impact beyond economic developments, political programs, and legislation. It also solves some of the apparent contradictions in neoliberal ideology, namely the seemingly incompatible imperatives of de-regulation on the one hand and government on the other: The ideology of complete freedom ultimately results in structures of restriction that are actualized not through overt force or regimentation but through internalization, rendering them all the more potent. Neoliberal governmentality thus merges these two contradictory demands.

Wacquant argues that neoliberal thought is actualized in four different spheres: the economic, the social, the penal, and the cultural. In the economic sphere, the narrative is one of entrepreneurial freedom and the conviction that human well-being will be advanced most effectively by "the extension of market or market-like mechanisms" (72). The realm of social policy, fittingly, is characterized by a "shift from protective welfare [...] to corrective workfare" (ibid.)-assistance is thus turned from a right to a conditional privilege. 
The "penal apparatus" (74) is drastically enlarged by "[e]xpansive and pornographic penal policy" (72), and Wacquant reminds us that this includes not only the ever growing prison population but also the increasing use of police force, "recourse to the courts" in all kinds of matters, the "hyperactivity of legislatures" (75), and, in general, the climate of fear and anxiety dominating the media and election campaigns. All of this ultimately results in "the bending of penal policy to emotive and symbolic parameters, in overt disregard for penological expertise" (75). Last, and for this context most important, the "organizational quadruped" (72) of neoliberalism is actualized in the "trope of individual responsibility as motivating discourse and cultural glue that pastes these various components of state activity together" (ibid.).

This "glue" can be traced across the entire cultural spectrum, from the booming self-help industry to Hollywood films, television series, and novels, from the advertising industry to the vast blogosphere that shows us how to optimize everything from our own bodies to our children and home décor. All these discursive formations congeal around the nodal points of self-management, optimization, transformation, and (physical, emotional, and intellectual) mobility. The meritocracy of affect propagated in the self-description of Princeton University, as I have shown in the previous chapter, is one instantiation of these dynamics; the images and narratives that constitute it reiterate and celebrate precisely these imperatives.

According to Mitchell Dean, neoliberal governmentality can be seen as constructing, via the above-mentioned and other channels, "a world of autonomous individuals, of 'free subjects"' (193). But, as he points out, this liberalism is highly ambivalent:

This is a subject whose freedom is a condition of subjection. The exercise of authority presupposes the existence of a free subject of need, desire, rights, interests and choice. However, its subjection is also a condition of freedom: in order to act freely, the subject must first be shaped, guided and moulded into one capable of responsibly exercising that freedom through systems of domination. Subjection and 'subjectification' are laid upon one another. Each is a condition of the other. (ibid.)

Julie Guthman calls this process "responsibilization" and argues that it generates a "hyper-vigilance about control and self-discipline" (193), as for instance in the context of 'health': 
$[\mathrm{N}]$ eoliberal governmentality produces contradictory impulses such that the neoliberal subject is compelled to participate in society both as an enthusiastic consumer and as a self-controlled subject. [...] Those who can achieve thinness amid this plenty are imbued with the rationality and self-discipline that those who are fat must logically lack. So, as thinness becomes a performance (and requisite) of success in a neoliberal world, it effectively becomes a criterion by which one is treated as a subject, a marker of deservingness in a political economy all too geared toward legitimizing such distinctions. Yet unlike the Puritan ethic, in which wanting less was a mark of salvation, the worthy neoliberal citizen must seem to want less while spending more. Spending money on becoming thin is the perfect solution for both neoliberal subjectivity and neoliberal capitalism more broadly. (ibid.)

The neoliberal subject, if it wants to be successful in reaping the rewards promised in the narratives and images currently in circulation, is thus encouraged to live in accordance with an ostensibly self-imposed regimen of optimization, structured by the imperatives of flexibility, transformation, mobility, and enthusiastic self-control.

\section{Prep in the Neoliberal Imagination}

While Michaels credits both Prep and Charlotte Simmons "for attempting to imagine an America in which the fact that some people have more money than others matters" he also places both of them squarely within the "neoliberal imagination" (93). The "imaginative world of neoliberalism" (101), according to Michaels, does not want to concern itself with class difference; indeed, at its very core is a desire not to counteract, nor even think about, socio-economic stratification. This makes perfect sense if we conceive of the neoliberal turn, with David Harvey, as "a political scheme aimed at [...] the restoration of class power" (29). Michaels argues convincingly that the neoliberal imagination reframes class along the lines of race and gender, thus suggesting that the issue lies not in the difference itself but in condescending or discriminatory treatment of the difference: "[T]he politics of the neoliberal imagination involve respecting the poor, not getting rid of poverty-eliminating inequality without redistributing wealth" (110).

What, then, is Michaels's reading of the novels in the context of the neoliberal imagination? Essentially, he expresses two major points of criticism: First, that while the scholarship novel as such is often thought to "expos[e] the injustices of class differences" at elite institutions, it really only pretends 
that there are class differences at these institutions to begin with (96). He is not wrong in pointing out the lack of socio-economic diversity at elite institutions, as the research conducted by the Equality of Opportunity Project has demonstrated. Because there is very little actual class diversity at these institutions, the scholarship novel, according to Michaels, fulfills the same function as "the (very few) poor people at Harvard," namely "to reassure the (very many) rich people at Harvard that you can't just buy your way into Harvard" (100).

Michaels's second point of criticism is his contention that Prep and Charlotte Simmons both rephrase the problem of socio-economic inequality in the language of identity politics, so that the problem is no longer the inequality itself, but what he terms the "'condescension' problem, the suggestion that at elite institutions, the poor are made to feel their poverty"(2005). Thus, according to Michaels, the issues faced by the novels' protagonists can be subsumed under the heading of 'classism'-precisely the pseudo-problem that the neoliberal imagination creates in order to mask the actual problem of socioeconomic inequality.

Michaels's reading is, in part, certainly convincing-particularly when one takes the macro-level of the genre of the campus novel into account. Almost all recent exemplars of the genre follow the same blue print of lower- or middleclass protagonists entering the elite educational space via a scholarship, and then having to find their way among their upper-class peers. Donna Tartt's The Secret History, Tobias Wolff's Old School, and Tom Perrotta's Joe College, to name but a few examples, all follow this structure. Incidentally, a similar phenomenon can be observed in the context of journalistic writing on the subject of elite education. Many of those who responded to William Deresiewicz's controversial critique of the Ivy League, for instance, were quick to establish their lower-(middle-)class credentials: Andrew Giambrone begins his article-suggestively titled "I'm a Laborer's Son. I went to Yale. I'm not trapped in a Bubble of Privilege"-by pointing out that he comes "from a family of construction workers and laundry-owners in Brooklyn, the descendants of Italian and Chinese immigrants, respectively," thus conflating his ethnic and socio-economic identities. J.D. Chapman, similarly, tells us in his first sentence that he "was born and raised in Roanoke, Virginia, a medium-sized city in the Blue Ridge mountains. It is not the sort of place that produces many Ivy League graduates." If one were to take campus novels and opinion pieces as the basis for an estimation of the socio-economic make up of elite schools and colleges, then, one would likely assume almost two thirds of the students to 
come from lower-middle-class families. These and countless other examples thus support Michaels's claim that much of the discourse of elite education revolves around the pretense of socio-economic diversity and the concomitant issues of discrimination or condescension, even though actual student bodies at elite institutions remain largely dominated by the upper and upper middle classes.

At the same time, however, Michaels's reading of Prep is reductive and superficial. When, in his closing paragraph, he sums up the neoliberal "desire not to have to get rid of class difference," he claims that this desire "[a]most always [...] takes the form of insisting that class doesn't matter; that, like Lee's mom says, being rich doesn't make you a better person" (2005). This, I argue, is an almost complete misreading of Prep, a novel that certainly demonstrates that class does matter and offers a complex account of its material and cultural foundations and reverberations. In the remainder of this section, I thus want to expand and complicate Michaels's take on Prep.

Reading Prep as both product and constituent of the neoliberal imagination makes sense for three reasons: The novel's production context, its publication context, and its chosen setting. Curtis Sittenfeld is a graduate of the Iowa Writers' Workshop at the University of Iowa. The creative writing program, as Mark McGurl argues in his seminal book The Program Era (2009), "stands as the most important event in postwar American literary history" (ix), and it is surely no coincidence that the success story of the writing program is largely coeval with the 'success' story of neoliberalism. Despite the evergrowing number of competitors, Iowa is doubtless the "best-known, mostestablished writing program in the country" (Delaney). As Loren Glass points out, in its attempts to streamline and standardize the process of becoming a successful writer, the "creative writing program as an institution exists at the intersection of contemporary neoliberalism and the creative class." Creativity, he argues, has been transformed into an integral part of the "ideology of the neoliberal era"- though surely he refers to a specific notion of creativity, efficient and goal-oriented, ultimately transmutable into something marketable.

Prep was not only produced but also published in a neoliberal context, as my discussion of the publicity and marketing campaign has illustrated, and it is safe to assume that Prep in some way reflects the neoliberal climate of its publication. In addition to the context of production and publication, the novel's setting - the elite boarding school-likewise encourages a reading through the lens of neoliberalism, since, as Michaels points out, educational institutions "loom larger" in the imaginative world of neoliberalism than they 
did in the liberal imagination, because they have become the dominant mechanism of legitimizing the current status quo of socio-economic stratification (2005): Rich people are rich because they are smart and ambitious and went to the right schools; poor people are poor because they are stupid and lazy and did not go to any school at all. The importance of education in the neoliberal imagination is also reflected in its penchant for the concept of the meritocracy, a system of hierarchization in which educational credentials play a pivotal role. If we assume, with Raymond Williams, "that there are clear social and historical relations between particular literary forms and the societies and periods in which they were originated or practiced" (182-3) it becomes imperative to read Prep both as a variant of the campus novel and the comingof-age story and as a part of the neoliberal imagination.

What, then, does it mean to ask whether a text is part of the neoliberal imagination? What is the neoliberal imagination? Are all novels produced in the neoliberal age part of the neoliberal imagination? Michaels, as we have seen above, defines the imaginative world of neoliberalism primarily in terms of what it renders invisible: class. In another article, in which he discusses the work of Michael Fried and Jacques Rancière, he describes the "neoliberal aesthetics" as one concerned with "the primacy of the beholder and [...] the subject" and diagnoses a "refusal of form" that is critical of "hierarchies of vision" but indifferent toward hierarchies produced by socio-economic factors. Critique within this neoliberal framework, according to Michaels, is always directed at "how we see ourselves and each other," but as class is not produced by how we see, it "cannot be overcome by seeing differently" (2011, my emphasis). Thus, Michaels argues, the aesthetics of anti-formalism are largely compatible with the politics of neoliberalism (Clune).

Employing the notion of governmentality here enables us to broaden the notion of the neoliberal imagination considerably and define it not only according to what it refuses to see, but also by why what it deems worthy of hypervisualization. Thinking about a neoliberal imagination or aesthetics assumes that there are certain forms of storytelling, certain modes of narration, certain images and imaginative inventories that are privileged within the hegemonic neoliberal governmentality. These might be narratives that mobilize certain neoliberal values or character traits-ambition, creativity, hard work, flexibility, individualism, transformation, success-and render invisible qualities that do not fit the mold of neoliberal subjectivity: exhaustion, depression, boredom, normalcy, failure, stagnation. It is interesting to note, in this context, that even narratives ostensibly critical of neoliberal ideation 
often follow these trajectories. For instance, the article about the young Dutch student activist mentioned above is titled "Beginning to Win: Amsterdam, Red Squares and the Student Struggle," thus evoking a standard struggleto-success narrative of winners and losers, and introduces the protagonist, Judith Baten, by pointing out that "[r]egardless of the fact that she had been averaging 2 hours of sleep for the last week, Baten was full of energy" (D'Astous and Gerlings). One might be tempted to point out that lack of sleep over a prolonged period of time is unhealthy, or that responding to sleep deprivation with an excess of energy is bordering on the pathological, but in the framework of the neoliberal imagination, descriptions such as this mobilize the topoi of resilience and perseverance and therefore inspire admiration rather than critique. Even those who are critical of and work to dismantle the neoliberal system-in this case, in the educational sphere-thus seem incapable of avoiding the tropes and the rhetoric of the neoliberal imagination.

Julie Levinson, in her 2012 book The American Success Myth on Film, examines a number of films ranging from the 1920 s to the present with regard to the way they articulate the myth of work and success in America. She argues that at the core of these and other expressions of the American success myth "lies the promise of mobility and self-making:"

Americans, these stories tell us, are endowed with the inalienable right to create an adult self out of whole cloth, rather than simply making do with the identity in which we find ourselves clad. We are active subjects rather than compliant objects of our personal destinies. Accidents of birth, rather than being implacable impediments to advancement, are merely challenges to be overcome through hard work. From log cabin to White House, from scruffy music club to arena rock superstardom, from the mailroom to the executive suite, the biographical and fictional heroes of success myth tales accomplish their rise through their single-minded application of the work ethic and their adherence to the individualist credo of competitive advantage. And if they can do it, these stories tell us, anyone and everyone can too if they want it badly enough. (21)

The cultural work in which these narratives engage, according to Levinson, is one of "normaliz[ing] the outliers. In a sort of cultural synecdoche, we extrapolate from the tales of people who have achieved significant social and vocational mobility the conviction that everyone in America can do the same" (22). These tales of rugged individualism, hard work, and steely determination, rendered in the dynamic language of inevitable progress and optimism, are 
of course not an invention of the neoliberal era but evolve from a much older American archetype, rooted in the Declaration of Independence, the mythology of the frontier, and the notion of American exceptionalism.

The entrepreneurial spirit invoked in these narratives is of course associated with capitalism as well as neoliberalism, but the cultural imperatives it generates differ considerably depending on the framework. The neoliberal modulation of this script is one of hyper-individuation: An intensified focus on one's self as one's most valuable capital and, at the same time, as a perpetual construction site-the project of self-optimization can never be completed. While the traditional, capitalist American Dream narrative focuses on prosperity, success, and upward mobility through externalized achievement, the neoliberal dream instantiates the self as the primary locus of optimization and marketization. Success is measured in the management and improvement of one's own body, one's psyche, one's affects and emotions; the individual, in the process, is turned into the insatiable investor, shareholder, and CEO of his or her own Self, Inc.

In thinking about plot structures, tropes, and topoi that seem particularly compatible with neoliberal sentiment, the question of genre arises almost naturally. In recent years, as Elliott and Harkins point out, scholars have increasingly focused on "the way in which various forms of literary and cultural genres participate in struggles over the meaning of neoliberalism and the aesthetic terms that should be used to define the political present" ( 1 ). In their own special issue of Social Text, titled "Genres of Neoliberalism," the editors attempt to "map the current temporal and territorial imaginaries animating genres of neoliberalism" (4) by collecting pieces that engage with various genres and expressions of neoliberal topoi-temporal structures in Filipino cinema; the dystopian fiction of Octavia Butler; agency in Latin American genres of precarious criminality; agency as burden in popular print genres; the 'noir' genre in novels and film. Other forms or modes of storytelling that have come under scrutiny with regard to the question of how they "register implementations of and resistance to neoliberalism" (Elliott and Harkins 6) are Reality TV-in particular the make-over narrative-and narratives of multiculturalism that, according to Michaels, expose "the utopian imagination of neoliberalism" by reframing socio-economic difference "not as an inequality to be eliminated but as a difference to be respected" (2006: 299).

Levinson likewise addresses the importance of genre in the context of the emergence and consolidation of the American success myth-genre, after all, describes sets of stories that "we tell [...] again and again [to] find com- 
fort in their formulaic assurance that hard work and virtue reliably yield upward mobility and happiness" (23). In addition to conventional rags-to-riches stories-Levinson's prime example is Gabriele Muccino's 2006 biographical drama The Pursuit of Happyness, a film perhaps impossible to outperform in terms of the purity of its ideological content-Levinson mentions coming-ofage stories and the traditional Bildungsroman, and thus brings us back to the text at the center of this discussion, Curtis Sittenfeld's Prep.

By virtue of its setting-the elite boarding school-and its spatial and temporal structure, Prep can readily be described as a campus novel. Most of the plot takes place on campus, with Lee only occasionally venturing into the outside world-the mall, the trip to Boston, the airport, Christmas breaks at home in Indiana. The novel's temporal structure, too, reflects its academic setting: Starting, in the first chapter, with Lee's freshman fall, each of the following seven chapter is "set in academic time" (Showalter 7)-freshman winter and spring; sophomore fall, junior fall, winter, and spring; senior year. The temporal and spatial boundedness might be said to raise certain expectations as to the protagonist's mobility-entering the elite educational space in the beginning, then moving through the four years, and exiting the space toward the end of the narrative.

Most of the reviews, however, employ a different genre marker and refer to Prep as a coming-of-age story (e.g. Hunt, Laken, Wood, Boss, EarthGoat, Schappell, among others). This is also what the descriptive paratext on Amazon and Goodreads says: "Curtis Sittenfeld's debut novel, Prep, is an insightful, achingly funny coming-of-age story as well as a brilliant dissection of class, race, and gender in a hothouse of adolescent angst and ambition." The decision to make use of the marker 'coming-of-age' might have been strategic-as we have seen in the beginning of this chapter, the campus novel is a term laden with conflicting associations; furthermore, the coming-of-age story seems to hold a quintessentially American appeal, alluding, as it does, to classics such as Mark Twain's Adventures of Huckleberry Finn (1884/85) and J.D. Salinger's The Catcher in the Rye (1951).

According to Jonathan Culler, genre markers function "to establish a contract between writer and reader so as to make certain relevant expectations operating, and thus to permit both compliance with and deviation from accepted modes of intelligibility" (172). What, then, are the expectations operative in the context of the coming-of-age narrative? Kenneth Millard, in his study Coming of Age in Contemporary American Fiction, traces the genre of the coming-of-age novel to its German predecessor, the Bildungsroman, a 
term coined in 1819 and referring to "a novel recounting the early emotional development and moral education of its protagonist" (2). The coming-of-age story, the Bildungsroman, and related genres such as the autobiography and the memoir commonly follow the same ritualized structure: "The protagonist [...] starts out as a novice, encounters and overcomes the challenges of adversity, and ends his or her story as a more mature adult character as a result of their experience" (3). Kirk Curnutt, writing about The Catcher in the Rye and Sylvia Plath's The Bell Jar, argues that " $\mathrm{t}]$ raditionally, adolescent fictions [...] caution against the stifling conformity, empty materialism, and false piety of the bourgeois home" (94). According to Schappell, readers might furthermore expect a "defining moment [...] where we feel that life will never be the same again, or some truth about human nature is revealed"-she offers the "Knowlesian Gene-and-Finny-in-the-tree scene" as an example. ${ }^{9}$ Mitchell adds to this by noting the importance of innocence in the dramatization of adolescence: "How is such innocence conceptualized and configured by these novels, what forms of social experience does it encounter, and what kind of maturity might it be said to achieve?" (5). In any case, it is safe to assume that the marker 'coming-of-age' is associated with expectations of development, transformation, emotional and intellectual mobility-the protagonist is expected to grow in, through, and against his or her environment.

As a private, elite boarding school, Ault is in many ways an exemplary institution of the neoliberal era. Funded through tuition, endowments, and gifts, these schools often offer sizable tax breaks for parents who enroll their children. Private schools are thus situated at that neoliberal juncture of insisting on independence and minimal state intervention on the one hand, and yet on the other hand still directly and indirectly relying on and profiting from public structures and public money. In the grander scheme of higher education in the United States, elite boarding schools furthermore symbolize the neoliberal tendency of rewarding the few and neglecting the many: While a small number of select schools command vast resources and boundless opportunities for their students, the great mass of public schools are suffering from budget cuts, growing class sizes, and a lack of well-trained and dedicated teachers.

One of the most famous examples of this is the formative moment in John Knowles's $A$ Separate Peace when the protagonist, Gene, out of jealousy causes his best friend Finny to fall from a tree, hurting himself badly. Much of the novel is concerned with Cene's attempts to understand his behavior and cope with his guilt. 
The value structure at Ault reflects the neoliberal modulation of traditional liberal values. The school's incentive structure is oriented toward competition, individual achievement, a well-developed work ethic, and the legitimization of privilege through a discourse of merit. These all figure in the liberal imagination as well. Lee's experience, however, demonstrates the degree to which the system has been permeated by neoliberal tendencies: At Ault, legitimization through merit works primarily through competitive distinction, through being better than one's peers-for instance through excelling academically, or by attaining positions such as the senior prefectship, or by becoming captain of one's sports team. Merit in Lee's environment is a flexible, multidimensional category that is not exclusively, or even predominantly, expressed through academic prowess. Even more importantly, as becomes clear in the course of the novel, those involved in the incentive structure care primarily about the success itself; the specific ways of achieving it are of secondary importance. This insistence on success for its own sake, in which the persuasive performance of liberal values is rewarded more than the actual engagement with them, is a product of the neoliberal imagination. Lee, however, refuses both sets of imperatives, the liberal and the neoliberal, and thus becomes a stumbling block in the system.

The process of infinite exclusification and the conception of this process as a zero-sum game mean, of course, that not everyone can be equally successful in this system. Failure is a part of Ault as it is of neoliberalism as such-but the novel demonstrates that those who fail do not fall too hard: Lee, despite her lack of accomplishments, is accepted at Mount Holyoke-one of the Seven Sisters and, according to Barron's Profiles of American Colleges, in the selectivity category "highly competitive plus"-and another student is "bitter now because he's going to Trinity" (378) instead of Harvard or Yale, even though, as Michaels points out, this is unlikely to have economic ramifications: "[T] he graduates of Trinity are also being ushered out of upper-middle-class adolescence into upper-middle-class adulthood" (2006: 100). In the neoliberal era just as before, capital, in all of its forms, is an effective tool to correct the failures of the individual.

\section{Conclusion: The Neoliberal Reader}

The reader-particularly when she is familiar with other coming-of-age stories set in educational spaces-is constantly waiting for that decisive moment that will set Lee's intellectual, psychosocial, or socio-economic development 
in motion: The falling out between Dink and his crowd in Stover at Yale; the tree scene in A Separate Peace; the murder in The Secret History; the cheating scandal in Old School; the rape in Charlotte Simmons. This does not happen for Lee, who points out that the "big occurrences in life, the serious ones, have for me always been nearly impossible to recognize because they never feel big or serious. In the moment, you have to pee, or your arm itches, or what people are saying strikes you as melodramatic or sentimental, and it's hard not to smirk" (211). As Valerie Laken puts it in her review, "we wait in vain for Lee to blossom and find her place in the world." In what is certainly one of the most interesting comments Prep makes with regard to the neoliberal imagination, Lee comments on her own stagnation and lack of mobility and, implicitly, on the readers' expectations:

I'd always loved the part in movies when a project, or even a person's whole life, came together: [...] the twenty-something woman who finally lost weight, dancing through aerobics classes, mopping her brow while she rode a gym bike, with a white towel around her neck, and then at last she emerged from the bathroom all cleaned up, bashful but beautiful (of course, she had no idea how beautiful), and her best friend hugged her before she left for the date or party that would be her triumph. I wanted to be that person, and I wanted the in-between time when I improved myself to glide by just that smoothly, with its own festive soundtrack. (262-3)

Lee's reflection on her desire for a montage is instructive for several reasons. First, this reflexivity demonstrates that Prep is certainly to a degree aware of its own status as a novel in the neoliberal era, and of its somewhat precarious position as an expression of and simultaneously a comment on neoliberalism. Second, it is surely no coincidence that she uses a woman's physical transformation of "finally los[ing] weight" as an example; I have commented above on the importance within the neoliberal imagination of disciplining one's body-particularly the female body. Third, it demonstrates Lee's misreading of sprezzatura: She wants the effortlessness to be real, not performative; she wants "the in-between time when I improved myself to glide by just that smoothly." This indicates that she has fundamentally misunderstood the imperatives of the neoliberal imagination.

Along with Lee, we wait in vain for this kind of montage. When she asks her tutor Aubrey whether she would be able to pass an important math exam, he answers in the affirmative, but only if she were "willing to work very hard" (262). This, to Lee, is "worse than if he'd just said no" (ibid.), because "to really 
learn precalculus would be laborious and miserable. Plus, it might still not work" (263). Lee thus does not even try; she is afraid of the discomfort and unwilling to take the risk of failure. During the math exam, she gives up after fifteen minutes. When her friend Martha enters the room, Lee represents the visual spectacle of failure: "I was lying on the futon, on my stomach, eating stale tortilla chips. I was hanging my head off the end of the futon so the crumbs would spill onto the floor, and the position was making blood rush into my face" (278). Lee has thus been turned into the specter of failure that haunts the neoliberal imagination: the lazy, timid slob. She nearly fails her math exam, and passes only because Martha does the work for her. Ultimately, Lee refuses to adhere to the imperatives of the merit narrative in both its liberal and neoliberal incarnations: She neither works hard nor performs well.

By playing with the reader's expectations and with the genre conventions of the coming-of-age story and the campus novel, Prep ultimately undermines and subverts the "normalcy of mobility" (Jones 12). I argue that, in resisting the conventional structure of the success myth and asking us to identity with a protagonist who-much to our dismay and discomfort-refuses to play along with the imperatives of the liberal and the neoliberal imagination, the narrative in fact creates a neoliberal reader. Her lack of self-discipline, of drive, of courage is offensive to us. We want Lee to grab herself by the bootstraps; we, in turn, want "to grab her by the collar, aggressively shake her, and help her avoid some of her regretful decisions" (Readfully), as one reviewer puts it; we want her to conform to the liberal notion of a sovereign, controlled, and deserving self. But we want this to happen in the neoliberal way: in the way of a smooth transformation, an inspirational performance of ease and mobility. The frustration with Lee's passivity and immobility is aggravated by the fact that she is a complicated protagonist; many readers experience difficulties and reluctance in their attempts to identify with her-she has been called "terribly unlikable" (Labell), "whiny and self-centered" (Writer in progress), a snob (Hulbert), a "willing cog in the machine of exclusion" (Schappell). Lee's racism and her arrogance toward those whom she believes to be in the lower echelons of the social taxonomy-Ms. Moray, Dave, Sin-Jun—add to these difficulties. Over long stretches, the novel thus makes it difficult to empathize with its protagonist.

Positioning the reader as a neoliberal subject creates a certain ambiguity. On the one hand, it might encourage a re-examination of neoliberal values and a questioning of the role of the elite education system in reproducing class structures. On the other hand, Prep individualizes and thus, to an ex- 
tent, depoliticizes Lee's class-based experiences. As one reviewer puts it, [“i]t would be very easy to blame the school's not-so-subtle caste system for Lee's problems and unhappiness, but Sittenfeld doesn't" (Schappell). If the novel does not engage in a criticism of the way elite institutions make class meaningful or a criticism of how class as a systemic factor informs and often obstructs an individual's development, then what does it do? Levinson argues that the American success myth is "sustained by widely disseminated stories, both fact-based and fictional, meant to demonstrate that mobility is largely a matter of individual agency" (22). Does Prep then simply invert the formula of the success myth by individualizing failure and holding Lee responsible for her own immobility?

\section{Diversity, Class, Mobility: Prep's Cultural Work}

The creation of a neoliberal reader and its ambivalent potential of subverting and affirming neoliberal values is one example of the complex processes of meaning production in which Prep engages. In the following I want to return to the notion of 'cultural work', introduced by Jane Tompkins in her study Sensational Designs: The Cultural Work of American Fiction, 1790-1860 (1985). Tompkins's premise is that cultural artifacts should not be studied for their inherent artistic or literary merit, but "because they offer powerful examples of the way a culture thinks about itself, articulating and proposing solutions for the problems that shape a particular historical moment" (xi). Since my overall research interest in this study is to understand the ways in which the United States via a number of different epistemological channels-institutional, fictional, academic, and aesthetic-makes sense of its own elite educational system, Tompkins's approach seems particularly appropriate and productive. Though I would not necessarily argue that the texts I am considering "have designs upon their audiences" (ibid.) in the sense that Tompkins uses the phrase, I do agree with her conceptualization of novels as "instruments of cultural self-definition" (xvi) and as "agents of cultural formation" (xvii). In the following section, I thus want to focus on the extent to which the novel gives room to questions and issues that preoccupy and destabilize the discourse of elite education.

An important distinction, in the context of Prep, has to be drawn between the measurable cultural work the text has inspired, becoming evident, for instance, in articles, reviews, and blog posts, and the potential for cultural work 